\title{
8-Hydroxydeoxyguanosine: a new potential independent prognostic factor in breast cancer
}

\author{
H Sova ${ }^{*, 1,2}$, A Jukkola-Vuorinen', U Puistola ${ }^{2}$, S Kauppila ${ }^{3}$ and P Karihtala ${ }^{1,2}$ \\ 'Department of Oncology and Radiotherapy, Oulu University Hospital, P.O. Box 22, FIN-90029, Finland; '2Department of Obstetrics and Gynecology, \\ Oulu University Hospital, P.O. Box 24, FIN-90029, Finland; ${ }^{3}$ Department of Pathology, Oulu University Hospital, P.O. Box 50, FIN-90029, Finland
}

BACKGROUND: 8-Hydroxydeoxyguanosine (8-oxodG) is the commonly used marker of oxidative stress-derived DNA damage. 8-OxodG formation is regulated by local antioxidant capacity and DNA repair enzyme activity. Earlier studies have reported contradictory data on the function of 8-oxodG as a prognostic factor in different cancer types.

METHODS: We assessed pre-operative serum 8-oxodG levels with an enzyme-linked immunosorbent assay in a well-defined series of 173 breast cancer patients. 8-OxodG expression in the nuclei of cancer cells from 150 of these patients was examined by immunohistochemistry.

RESULTS: The serum 8-oxodG levels and immunohistochemical 8-oxodG expression were in concordance with each other $(P<0.05)$. Negative 8-oxodG immunostaining was an independent prognostic factor for poor breast cancer-specific survival according to the multivariate analysis $(P<0.01)$. This observation was even more remarkable when ductal carcinomas only $(n=140)$ were considered $(P<0.00 \mathrm{I})$. A low serum 8-oxodG level was associated statistically significantly with lymphatic vessel invasion and a positive lymph node status.

CONCLUSIONS: Low serum 8-oxodG levels and a low immunohistochemical 8-oxodG expression were associated with an aggressive breast cancer phenotype. In addition, negative 8-oxodG immunostaining was a powerful prognostic factor for breast cancer-specific death in breast carcinoma patients.

British Journal of Cancer (2010) I 02, 1018 - 1023. doi: I0.1038/sj.bjc.6605565 www.bjcancer.com

Published online 23 February 2010

(C) 2010 Cancer Research UK

Keywords: 8-oxodG; DNA repair; immunohistochemistry; oxidative stress; reactive oxygen species

Reactive oxygen species (ROS), despite being products of normal cellular metabolism, are considered to have a substantial influence on the development of cancer, in part, because of their ability to react with DNA. For example hydroxyl radical $(\bullet \mathrm{OH})$ can react with pyrimidines, purines and chromatin protein resulting in base modifications, genomic instability and alterations in gene expression. These reactions in connection with oncogenes or tumour suppressor genes may result in the initiation of cancer (Loft and Poulsen, 1996). Several recent studies have shown high ROS levels in carcinoma cells compared with the surrounding healthy tissue (reviewed in Karihtala and Soini, 2007). Under normal conditions, ROS are maintained within narrow boundaries by scavenging systems, such as superoxide dismutases, peroxiredoxins (Prx) and glutathione-related antioxidant defences. Consequently, when the amount of ROS exceeds the capacity of the ROS scavenging systems, oxidative stress occurs and this imbalanced redox status leads to an increase in damage to DNA.

A direct measurement of ROS is challenging because of their short lifetime and immediate reaction with redox state regulating components. For instance, it has been estimated that the lifespan of $\bullet \mathrm{OH}$, the most harmful ROS, is $<1 \mathrm{~ns}$ (Valko et al, 2004). Therefore, a useful method to assess ROS is the use of antibodies

*Correspondence: H Sova; E-mail: henrijuh@mail.student.oulu.fi Received 20 October 2009; revised 7 January 20 I0; accepted 12 January 20I0; published online 23 February 2010 against the specific 'footprints' of oxidative damage. 8-Hydroxydeoxyguanosine (8-oxodG) is a specific marker of $2^{\prime}$-deoxyguanosine damage after ROS attack to DNA. 8-OxodG is one of the most widely used oxidative stress biomarkers, and it can be measured with immunohistochemistry and, for example by enzyme-linked immunosorbent assay (ELISA) or high pressure liquid chromatography, with mass spectrometric or electrochemical detection (HPLC-MS/MS; HPLC-EC) in serum or urine samples (Cooke et al, 2008). There are currently no data as to whether systemic 8-oxodG levels are associated with 8-oxodG modifications in situ in any disease or whether serum or immunohistochemical assessment of 8-oxodG could be used as a prognostic factor in breast cancer.

In this study, we analysed serum 8-oxodG levels and 8-oxodG tissue expression from breast carcinoma patients and correlated the results with clinicopathological parameters such as the stage, grade and lymphatic and blood vessel invasion status. The function of 8-oxodG as a prognostic factor in breast cancer and correlation between serum 8-oxodG levels and 8-oxodG breast carcinoma tissue expression was evaluated.

\section{MATERIALS AND METHODS}

The study material consisted of 173 pre-operative venous blood samples from breast carcinoma patients, which were acquired 
from the files of the Department of Oncology, Oulu University Hospital from 2003 to 2005. In addition, we were able to acquire 150 out of 173 tumour blocks from these patients for immunohistochemical analysis. The tumour blocks were collected from the archives of the Department of Pathology, Oulu University Hospital. The study was approved by the Local Ethics Committee.

Blood samples were taken before primary operations and serum samples were stored in polypropylene or polystyrene tubes at $-80^{\circ} \mathrm{C}$ until the time of analysis. The breast cancer tissue samples were fixed in neutral formalin and embedded in paraffin. The malignancy grades in the cancerous lesions were determined according to the WHO classification (Tavassoli and Devilee, 2003) by pathologist (SK). The material comprised 140 ductal carcinomas, 25 lobular carcinomas and 8 other types of breast carcinomas. The clinical data were sourced from the records of Oulu University Hospital. The most important patient and tumour characteristics are shown in Table 1. The mean follow-up time of the subjects was 40.5 months.

The serum levels of 8-oxodG were determined using an ELISA using the Highly Sensitive 8-OHdG kit, which was obtained from the Japan Institute for the Control of Aging, Fukuroi, Japan. The kit uses an anti 8-oxodG monoclonal antibody (clone N45.1),

Table I Patient and tumour characteristics

\begin{tabular}{|c|c|c|c|c|}
\hline & $\begin{array}{c}\text { Ductal } \\
\text { carcinoma } \\
(n=\mid 40)\end{array}$ & $\begin{array}{c}\text { Lobular } \\
\text { carcinoma } \\
(n=25)\end{array}$ & $\begin{array}{c}\text { Other } \\
\text { carcinomas } \\
(n=8)\end{array}$ & $\begin{array}{c}\text { Total } \\
(n=173)\end{array}$ \\
\hline $\begin{array}{l}\text { Average age (years) } \\
\text { Grade }\end{array}$ & $56.4 \pm 12.1$ & $58.2 \pm 16.7$ & $66.5 \pm 13.3$ & $57.1 \pm 13.0$ \\
\hline I & $18(12.9 \%)$ & $2(8 \%)$ & $7(87.5 \%)$ & $26(15.6 \%)$ \\
\hline$\|$ & $64(45.7 \%)$ & $19(76 \%)$ & I (I2.5\%) & $83(48.6 \%)$ \\
\hline III & $58(41.4 \%)$ & $4(16 \%)$ & $0(0 \%)$ & $62(35.8 \%)$ \\
\hline \multicolumn{5}{|l|}{$T$} \\
\hline I & 89 (63.6\%) & $16(64 \%)$ & $5(62.5 \%)$ & $110(63.6 \%)$ \\
\hline 2 & $44(31.4 \%)$ & $8(32 \%)$ & $3(37.5 \%)$ & $55(31.8 \%)$ \\
\hline $3+4$ & 7 (5\%) & I (4\%) & $0(0 \%)$ & 8 (4.7\%) \\
\hline \multicolumn{5}{|l|}{ N } \\
\hline 0 & $75(53.6 \%)$ & $14(56 \%)$ & $8(100 \%)$ & $97(56.1 \%)$ \\
\hline 1 & $58(41.4 \%)$ & $8(32 \%)$ & $0(0 \%)$ & $66(38.2 \%)$ \\
\hline 2 & 7 (5\%) & $3(12 \%)$ & $0(0 \%)$ & $10(5.8 \%)$ \\
\hline \multicolumn{5}{|l|}{ HER-2 } \\
\hline Positive & $20(14.3 \%)$ & $2(8 \%)$ & $0(0 \%)$ & $22(12.7 \%)$ \\
\hline Negative & $120(85.7 \%)$ & $23(92 \%)$ & $8(100 \%)$ & | 51 (87.3\%) \\
\hline \multicolumn{5}{|l|}{ Estrogen receptor } \\
\hline Positive & 107 (76.4\%) & $25(100 \%)$ & $8(100 \%)$ & | 40 (80.9\%) \\
\hline Negative & $33(23.6 \%)$ & $0(0 \%)$ & $0(0 \%)$ & $33(19.1 \%)$ \\
\hline \multicolumn{5}{|l|}{ Progesterone receptor } \\
\hline Positive & $90(64.3 \%)$ & $19(76 \%)$ & 7 (87.5\%) & $116(67.1 \%)$ \\
\hline Negative & $50(35.7 \%)$ & $6(24 \%)$ & I (I2.5\%) & 57 (32.9\%) \\
\hline \multicolumn{5}{|c|}{ Lymphatic vessel invasion } \\
\hline Yes & $15(10.7 \%)$ & $0(0 \%)$ & I (I2.5\%) & $16(9.2 \%)$ \\
\hline No & $119(85.0 \%)$ & $25(100 \%)$ & $7(87.5 \%)$ & |5| (87.3\%) \\
\hline Unknown & $6(4.3 \%)$ & & & $6(3.5 \%)$ \\
\hline \multicolumn{5}{|l|}{ Blood vessel invasion } \\
\hline Yes & $9(6.4 \%)$ & $0(0 \%)$ & $0(0 \%)$ & $9(5.2 \%)$ \\
\hline No & $125(89.3 \%)$ & $25(100 \%)$ & $8(100 \%)$ & $158(91.3 \%)$ \\
\hline Unknown & $6(4.3 \%)$ & & & $6(3.5 \%)$ \\
\hline \multicolumn{5}{|l|}{ Treated with } \\
\hline Radiotherapy & $|3|(93.6 \%)$ & $23(92 \%)$ & $4(50 \%)$ & $158(91.3 \%)$ \\
\hline Chemotherapy & $75(53.6 \%)$ & $7(28 \%)$ & $0(0 \%)$ & $82(47.4 \%)$ \\
\hline Hormonal therapy & $60(42.9 \%)$ & $10(40 \%)$ & $0(0 \%)$ & $70(40.5 \%)$ \\
\hline
\end{tabular}

which is highly specific for 8-oxodG. The ELISA assay was performed according to the manufacturer's instructions with a few divergences. At first, we pre-processed all serum samples using Millipore Microcon filters. Filters were damped with $100 \mu \mathrm{l}$ of distilled water and subsequently centrifuged in $14.000 \mathrm{~g}$ for $5 \mathrm{~min}$. Then filters were turned around and centrifuged for another $5 \mathrm{~min}$ to remove remaining water. Damped filters were moved to new tubes and $200 \mu \mathrm{l}$ of serum sample was added into each tube and then centrifuged for $30 \mathrm{~min}$ in $14.000 \mathrm{~g}$. Next, the primary antibody was reconstituted with the primary antibody solution. Then $50 \mu \mathrm{l}$ of sample or standard were added to wells, doing duplicate for each. After that, $50 \mu \mathrm{l}$ of reconstituted primary antibody was added to each well. Plate was shaken and covered with adhesive strip and then incubated at $4{ }^{\circ} \mathrm{C}$ for over night. After incubation, the contents of the wells were poured off and each well was washed with $250 \mu \mathrm{l}$ of washing solution three times. Then secondary antibody was reconstituted with the secondary antibody solution; $100 \mu \mathrm{l}$ of constituted secondary antibody was added to each well. Next, the plate was shaken, covered with adhesive strip and then incubated for $1 \mathrm{~h}$ at room temperature. Washing was repeated at the end of the incubation period. After that, a substrate solution was prepared and $100 \mu \mathrm{l}$ of it was added to each well and the plate was shook. The plate was incubated in the dark for $15 \mathrm{~min}$ at room temperature. Then $100 \mu \mathrm{l}$ of reaction terminating solution was added to each well and the plate was shook. Absorbances were measured at $450 \mathrm{~nm}$ in a plate reader and standard curve was used to determine the amount of 8-oxodG in samples. We assayed the duplicates of each sample and used also the outermost wells of the microtiter plate. With this method, we were able to assay 41 samples in one plate. The 8-oxodG concentrations from the duplicate samples were extremely close to each other throughout the analysis, and if they differed to $>10 \%$, they were assayed again. Four out of 173 samples were re-assayed because of over $10 \%$ variance between duplicates.

For immunohistochemistry, the paraffin-embedded breast lesions were first sectioned on slides of $4 \mu \mathrm{m}$ thickness and placed on SuperFrostPlus glass (Menzel-Glāser, Germany). To remove the paraffin, they were soaked in xylene and then rehydrated in a graded alcohol series. They were heated in a microwave oven in $10 \mathrm{~mm}$ of citric acid monohydrate for $10 \mathrm{~min}$ to predigest the sections, and then chilled at room temperature. The sections were immersed in $3 \%$ hydrogen peroxide in methanol for $15 \mathrm{~min}$ to consume the endogenous peroxide. The slides were incubated with a 1:125 primary antibody dilution against 8-oxodG (Mouse monoclonal 8-oxodG antibody, Gentaur, Belgium) overnight at $+4^{\circ} \mathrm{C}$. Both ELISA kit and immunostainings were based on the same 8-oxodG antibody (N45.1) (Toyokuni et al, 1997). Immunostaining was carried out by using a biotinylated secondary antibody 1:400 dilution with an avidin-biotinperoxidase complex (Dakopatts, Glostrup, Denmark). Aminoethyl carbazole (Zymed Laboratories Inc., South San Francisco, California, USA) was used as a chromogen. Immersed in $2 \%$ ammonia water, Meyer's haematoxylin was used for counterstaining, and in the end, the sections were mounted with ImmuMount (Shandon, Pittsburgh, PA, USA).

The intensity of the 8-oxodG immunostainings from the nuclei of cancer cells was evaluated by dividing the staining reaction into four groups: $-=$ negative immunostaining $(<5 \%$ of tumour cells showing nuclear positivity), $+=$ weak immunostaining (5-20\% of tumour cells showing nuclear positivity), $++=$ moderate immunostaining $(21-80 \%$ of tumour cells showing nuclear positivity) and $+++=$ strong immunostaining ( $>80 \%$ of tumour cells showing nuclear positivity). For statistical analysis, we divided the immunostaining results into two groups: negative $(-)$ and positive $(+,++,+++)$ immunostaining. The distribution of the immunostaining groups is shown in Table 2. 
Table 2 Distribution of 8-oxodG immunostaining

\begin{tabular}{lcc}
\hline & All patients $(\boldsymbol{n}=\mathbf{I 5 0})$ & Ductal carcinomas $(\boldsymbol{n}=\mathbf{I 2 3})$ \\
\hline- & $23(15.3 \%)$ & $17(13.8 \%)$ \\
+ & $23(15.3 \%)$ & $23(18.7 \%)$ \\
++ & $64(42.7 \%)$ & $53(43.1 \%)$ \\
+++ & $40(26.7 \%)$ & $30(24.4 \%)$ \\
\hline
\end{tabular}

Abbreviation: 8-oxodG = 8-hydroxydeoxyguanosine.

SPSS 15.0 for Windows and R-language were used for statistical analysis. The significance of the associations was defined using the Spearman's test, Mann-Whitney $U$-test and Pearson $\chi^{2}$-test with Fisher's two-sided exact test for 8-oxodG ELISA and 8-oxodG immunohistochemistry, respectively. Survival was analysed with the Kaplan-Meier curve with log-rank, Tarone - Ware and Breslow tests. Cox multivariate regression analysis was used for multivariate analysis. The probability values $<0.05$ were considered significant. We also cooperated with a statistics expert as needed.

\section{RESULTS}

The 8-oxodG serum levels and tissue expression of the whole patient group, and separately of the patients with ductal carcinoma, were compared with several known tumour characteristics. The presence of lymphatic invasion, blood vessel invasion, lymph node metastases, expression of oestrogen receptor, progesterone receptor, HER-2, Ki-67 and p53 were classified as either positive or negative for statistical analyses. The grading and tumour size were divided into the following subgroups: grade I group, grade II - III group, $\mathrm{T} 1$ group and $\mathrm{T} 2-4$ group.

When the characteristics were compared within the whole patient group, the lower serum 8-oxodG levels were associated with lymphatic vessel invasion $(P<0.05)$ and positive lymph node status $(P<0.05)$ (Table 3$)$. Among the ductal carcinoma patients, similarly low serum 8-oxodG levels correlated with poor differentiation $(P<0.05)$, lymphatic and blood vessel invasions $(P<0.05)$ and node status $(P<0.01)$. Serum 8 -oxodG was not a statistically significant prognostic factor in either the whole or the ductal cancer patient groups.

The 8-oxodG immunostaining localised subcellularly to nuclei (Figure 1). Negative 8-oxodG immunostaining correlated with negative HER-2 $(P<0.05)$ and p53 $(P<0.05)$ expression within the whole study group. In addition, negative 8-oxodG immunostaining was associated with positive node status among ductal carcinoma patients $(P<0.05)$. The 8 -oxodG levels from serum and 8-oxodG tissue expression correlated positively with each other according to the Spearman's test $(P<0.05$, correlation coefficient 0.163 ). Neither serum nor immunohistochemical 8 -oxodG were associated with the patient age or menopausal status.

Patients with negative 8-oxodG immunostaining had a higher risk of breast cancer-specific death compared with patients with positive 8-oxodG immunostaining (Kaplan-Meier, log-rank analysis $P<0.01$; Figure 2). Survival statistics are shown in Table 4. In the Cox multivariate analysis, a negative 8-oxodG immunohistochemistry was an independent prognostic factor of poor survival when tumour size, node status, grade, Ki-67, HER-2, p53 and receptor status were taken into account.

\section{DISCUSSION}

In this study, we show for the first time that negative 8-oxodG immunostaining in breast cancer cells is an independent prognostic factor for poorer prognosis and that low serum and tissue
Table 3 Mean serum 8-oxodG levels and s.d. in the groups of conventional prognostic factors

\begin{tabular}{|c|c|c|}
\hline & Mean 8-oxodG (ng ml- $\left.\mathrm{ml}^{-1}\right)$ & $P$-value \\
\hline \multicolumn{3}{|c|}{ Tumor size $(T)$} \\
\hline 1 & $0.18 \pm 0.13$ & NS \\
\hline $2-4$ & $0.15 \pm 0.11$ & \\
\hline \multicolumn{3}{|c|}{ Nodal status (N) } \\
\hline 0 & $0.18 \pm 0.12$ & $P<0.05$ \\
\hline $1-2$ & $0.15 \pm 0.13$ & \\
\hline \multicolumn{3}{|l|}{ Grade } \\
\hline $1-2$ & $0.17 \pm 0.12$ & NS \\
\hline 3 & $0.17 \pm 0.13$ & \\
\hline \multicolumn{3}{|c|}{ Lymphatic vessel invasion } \\
\hline Yes & $0.12 \pm 0.09$ & $P<0.05$ \\
\hline No & $0.17 \pm 0.13$ & \\
\hline \multicolumn{3}{|c|}{ Blood vessel invasion } \\
\hline Yes & $0.10 \pm 0.04$ & NS \\
\hline No & $0.17 \pm 0.13$ & \\
\hline \multicolumn{3}{|l|}{ ER expression } \\
\hline Positive & $0.16 \pm 0.12$ & NS \\
\hline Negative & $0.19 \pm 0.14$ & \\
\hline \multicolumn{3}{|l|}{ PR expression } \\
\hline Positive & $0.16 \pm 0.12$ & NS \\
\hline Negative & $0.19 \pm 0.13$ & \\
\hline \multicolumn{3}{|l|}{ Ki-67 } \\
\hline $0-2$ & $0.16 \pm 0.12$ & NS \\
\hline 3 & $0.19 \pm 0.14$ & \\
\hline \multicolumn{3}{|l|}{ Her-2 } \\
\hline Positive & $0.15 \pm 0.09$ & NS \\
\hline Negative & $0.17 \pm 0.13$ & \\
\hline \multicolumn{3}{|l|}{ Histology } \\
\hline Ductal & $0.17 \pm 0.13$ & NS \\
\hline Other & $0.16 \pm 0.13$ & \\
\hline
\end{tabular}

Abbreviations: $E R=$ oestrogen receptor; $N S=$ no statistical significance; $P R=$ progesterone receptor; 8-oxodG =8-hydroxydeoxyguanosine.

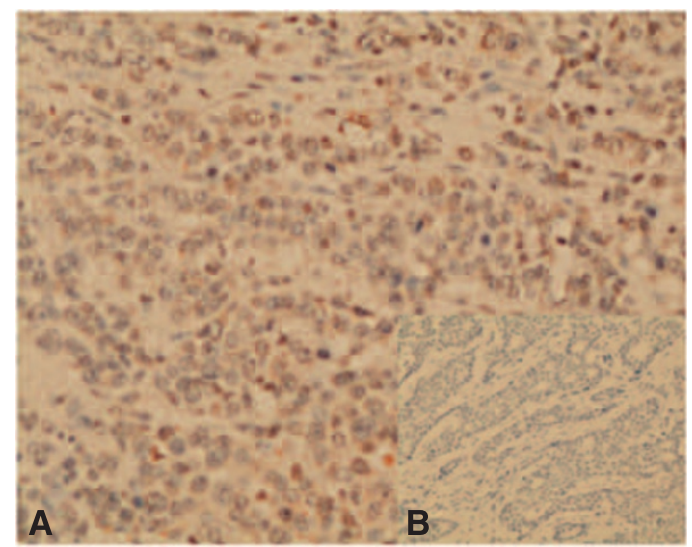

Figure I An example of highly positive $(\mathbf{A})($ magnification $\times 210)$ and negative $(\mathbf{B})$ (magnification $\times 105)$ 8-oxodG immunostaining.

levels of 8-oxodG are characteristic of more aggressive breast cancer. 8-OxodG is one of the most widely used biomarkers of oxidative stress, mainly because of its abundance in DNA and also 
A

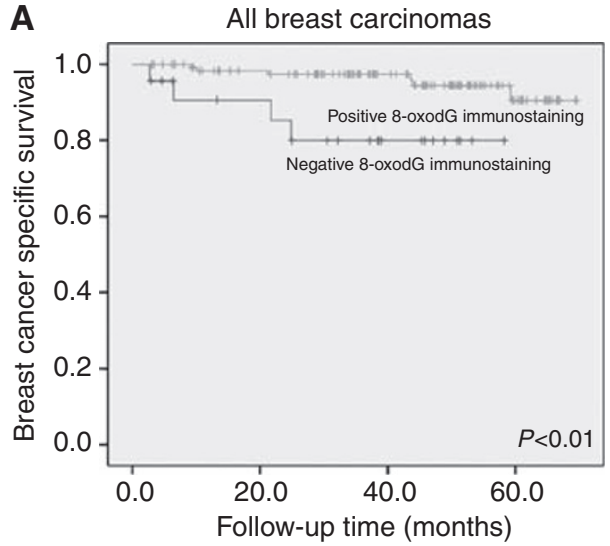

B

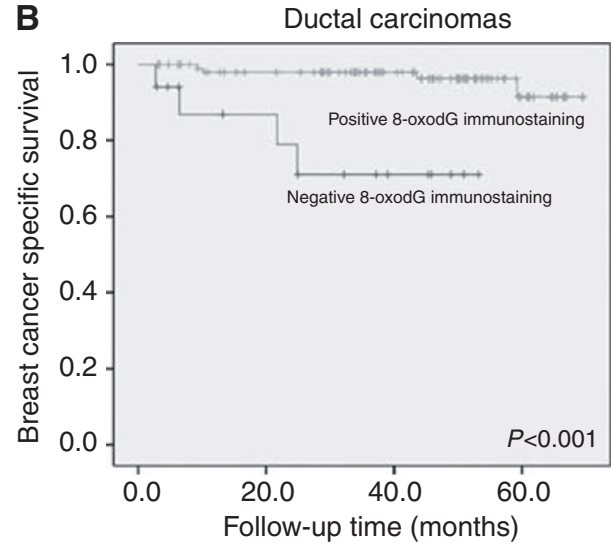

Figure 2 Kaplan-Meier curves showing breast cancer-specific survival when immunohistochemical 8-oxodG staining is divided into either negative or positive: $(\mathbf{A})$ all carcinomas $(\log -r a n k P<0.0 \mathrm{I})$ and $(\mathbf{B})$ ductal carcinomas only (log-rank $P<0.00 \mathrm{I})$.

because of its reliable detectability (Karihtala and Soini, 2007). Compared with other bases, guanine most readily undergoes an oxidative attack in the presence of ROS (Peoples and Karnes, 2005). 8-OxodG can induce $\mathrm{GC} \rightarrow \mathrm{TA}$ transversion mutations particularly during DNA replication and thus, if these oxidative lesions are not repaired, they can become mutagenic (Peoples and Karnes, 2005). There is a rather broad consensus that extracellular 8-oxodG levels are not affected by diet, cell death or artefactual formation (Cooke et al, 2005). However, this is the first study to show that oxidative stress observed in cancer cells reflects a good correlation to the serum 8-oxodG levels. Therefore, it seems that serum 8-oxodG in breast cancer patients mainly originates from tumour tissue.

Earlier, many studies examining oxidatively damaged DNA in carcinogenesis have discovered augmented 8-oxodG levels in either the urine or tumour tissue DNA compared with the healthy tissue. For example, in studies on breast carcinomas, the 8-oxodG levels have been reported as being 8 to 17 times higher in comparison with those in healthy breast tissue (Matsui et al, 2000). Elevated levels of 8-oxodG from cancer patients compared with healthy subjects have also been observed in lung cancer (Vulimiri et al, 2000; Shen et al, 2007), basal cell carcinoma (Nishigori et al, 2005), bladder cancer (Kaczmarek et al, 2005), acute lymphoblastic leukaemia (Sentürker et al, 1997), colorectal cancer (Oliva et al, 1997), high grade cervical dysplasia (Romano et al 2000), renal cell carcinoma (Okamoto et al, 1994), prostate cancer (Miyake et al, 2004), gastric intestinal metaplasia (Farinati et al, 2008) and gastric adenocarcinoma (Lee et al, 1998). Evidence from these studies suggests that elevated 8-oxodG levels in these malignant or premalignant diseases compared with healthy individuals would be a sign of increased oxidative stress, impaired antioxidant defence or inadequate repair of oxidatively damaged DNA. A recent study showed a highly significant decrease of 8-oxodG serum levels after breast cancer surgery compared with preoperative levels (Cho et al, 2009). However, there are also some reports that have found no difference in the 8-oxodG levels between cancer patients and healthy subjects (Nagashima et al, 1995; Jałoszyñski et al, 2003).

In this study, low immunohistochemical expression and low pre-operative serum 8-oxodG levels were strongly associated with conventional prognostic factors for aggressive breast cancer such as positive lymph node status and lymphovascular invasion. This significant association was even more obvious among ductal carcinomas, which is the main histological subtype of breast cancer with a highly variable prognosis and, therefore, more accurate prognostic factors are needed especially for this histological breast cancer subtype. In parallel with this, the presence of 8-oxodG immunostaining correlated with positive HER-2 status and high p53 expression. HER-2 is a one of the most widely used tumour markers in breast cancer, and HER-2 gene amplification results in poor prognosis, resistance to hormonal therapies and generally to more aggressive breast cancer phenotype (Slamon et al, 1987; Ross et al, 2009). p53 is a tumour suppressor protein, whose physiological function is highly essential in safeguarding DNA integrity (Barnes and Camplejohn, 1996). The co-expressions between 8-oxodG and p53 and HER-2 are probably because of the nature of 8 -oxodG as a marker of oxidative stress-derived DNA mutations in general and suggest that ROS has a function in the formation of HER-2 and p53 mutations. Earlier, ROS-derived GC $\rightarrow$ TA transversions have been observed in the 53 gene in vivo in lung and liver cancers (Hussain et al, 2000; Cooke et al, 2006).

Furthermore, according to our results, negative 8-oxodG immunostaining from tumour tissue could be used as an independent prognostic factor for poor breast cancer-specific survival. Earlier, two groups have reported that low 8-oxodG levels either in tumour tissue or in urine of breast cancer patients are associated with a higher stage or grade (Matsui et al, 2000; Kuo et al, 2007). In both of these studies, 8-oxodG levels were elevated in cancer patients compared with healthy controls. However, these studies were smaller than ours and no associations between 8-oxodG and survival were reported. In a study by Dincer et al (2007), the 8-oxodG plasma levels were significantly higher in controls than in gastric and colon carcinoma patients, which is also in line with our results. However, high 8-oxodG levels from tumour tissue DNA have also been reported as an independent prognostic factor of poor survival in lung cancer and hepatocellular carcinoma (Matsumoto et al, 2003; Shen et al, 2007). This emphasizes the diverse prognostic function of 8-oxodG in different malignancies.

There are several possible mechanisms behind the inverse association of 8-oxodG levels and tumour aggressiveness. Low serum, plasma or urine levels of 8-oxodG can be a sign of enfeebled repair of oxidatively damaged DNA or enhanced antioxidant defence rather than low ROS production. The main repair enzyme for 8-oxodG is human 8-oxoguanine DNA glycosylase 1 (hOGG1) and its proper function is crucial for the prevention of $\mathrm{G}$ to $\mathrm{T}$ transversion mutations (Hirano, 2008). Reduced hOGG1 levels significantly increase relative risk for initiation of carcinomas (Paz-Elizur et al, 2003, 2006). With impaired hOGG1 function, cells are not able to cleave damaged guanosine from DNA, which results in lower 8-oxodG levels in extracellular 
Table 4 Survival statistics for 8-oxodG immunohistochemistry and conventional risk factors

\begin{tabular}{|c|c|c|c|}
\hline & $\begin{array}{l}\text { Patients } \\
(n=173)\end{array}$ & $\begin{array}{c}\text { Mean survival } \\
\text { (months) }\end{array}$ & $\begin{array}{c}P \text {-value } \\
\text { for BCSS }\end{array}$ \\
\hline \multicolumn{4}{|l|}{ Tumor size $(T)$} \\
\hline I & 110 & 68.7 & \multirow[t]{2}{*}{$<0.01$} \\
\hline $2-4$ & 63 & 63.5 & \\
\hline \multicolumn{4}{|c|}{ Nodal status (N) } \\
\hline 0 & 97 & 70.4 & \multirow[t]{2}{*}{$<0.01$} \\
\hline $1-2$ & 76 & 62.6 & \\
\hline \multicolumn{4}{|l|}{ Grade } \\
\hline $1-2$ & 110 & 70.0 & \multirow[t]{2}{*}{$<0.01$} \\
\hline 3 & 63 & 62.1 & \\
\hline \multicolumn{4}{|c|}{ Lymphatic vessel invasion } \\
\hline Yes & 16 & 55.6 & \multirow[t]{2}{*}{ NS } \\
\hline No & 151 & 67.9 & \\
\hline \multicolumn{4}{|c|}{ Blood vessel invasion } \\
\hline Yes & 9 & 58.2 & \multirow[t]{2}{*}{ NS } \\
\hline No & 158 & 67.6 & \\
\hline \multicolumn{4}{|l|}{ ER expression } \\
\hline Positive & 140 & 69.0 & \multirow[t]{2}{*}{$<0.01$} \\
\hline Negative & 33 & 55.9 & \\
\hline \multicolumn{4}{|l|}{$P R$ expression } \\
\hline Positive & 116 & 67.5 & \multirow[t]{2}{*}{$<0.05$} \\
\hline Negative & 57 & 64.3 & \\
\hline \multicolumn{4}{|l|}{$\mathrm{Ki}-67$} \\
\hline $0-2$ & 127 & 69.6 & \multirow[t]{2}{*}{$<0.001$} \\
\hline 3 & 46 & 56.7 & \\
\hline \multicolumn{4}{|l|}{ Her-2 } \\
\hline Positive & 22 & 60.8 & \multirow[t]{2}{*}{ NS } \\
\hline Negative & 151 & 67.6 & \\
\hline \multicolumn{4}{|l|}{ Histology } \\
\hline Ductal & 140 & 66.4 & \multirow[t]{2}{*}{ NS } \\
\hline Other & 33 & 67.7 & \\
\hline \multicolumn{4}{|c|}{ 8-oxodG immunohistochemistry } \\
\hline Positive & 127 & 66.9 & \multirow[t]{2}{*}{$<0.01$} \\
\hline Negative & 23 & 49.5 & \\
\hline \multicolumn{4}{|c|}{ 8-oxodG immunohistochemistry ductal histology } \\
\hline Positive & 106 & 67.4 & \multirow[t]{2}{*}{$<0.001$} \\
\hline Negative & 17 & 42.1 & \\
\hline
\end{tabular}

Abbreviations: $B C S S=$ Breast cancer specific survival; $E R=$ oestrogen receptor; $N S=$ no statistical significance; $P R=$ progesterone receptor; 8-oxodG $=8$-hydroxydeoxyguanosine. fluids. However, defects in DNA repair do not explain low 8-oxodG expression in the tumour tissue of the most aggressive breast carcinomas. High ROS production in tumour tissue promotes the over-expression of antioxidant proteins, such as thioredoxins and Prx, which are associated with malignant transformation in breast cancer (Karihtala et al, 2003; Turunen et al, 2004). In addition, promoted antioxidant defence in tumour tissue could offer a growth advantage to cancer cells by avoiding apoptosis and necrosis caused by ROS. Overproduced antioxidant enzymes would prevent ROS interaction with DNA leading to decreased formation of 8-oxodG at tissue level as suggested by the current results. Transcription factor NF-E2-related factor 2 (Nrf2), the major up-regulator of multiple antioxidant enzymes (e.g. peroxiredoxin I, thioredoxin reductase), has a highly important function in eliminating ROS from the cells. On the other hand, Nrf2 up-regulation, which is commonly seen in chemoresistant cell lines, may provide growth advantage to cancer cells during oncological treatments (Lau et al, 2008, Singh et al, 2008). Although the clinical data is currently lacking from breast cancer patients, Nrf2 up-regulation and consequent antioxidant enzyme induction and chemoresistance may explain why the patients with the worst prognosis have low 8-oxodG levels at the initial situation.

The function of oxidative stress has also been studied in some non-malignant diseases (Evans and Cooke, 2006). Interestingly, low levels of 8-oxodG have been reported in the urine of systemic lupus erythematosus patients and in cerebrospinal fluid of patients with Alzheimer's disease when compared with healthy subjects (Evans and Cooke, 2006; Farinati et al, 2008). These authors also concluded that low 8-oxodG levels should be taken as evidence of impaired DNA repair of 8-oxodG.

We conclude that immunohistochemical 8-oxodG expression is associated with the serum 8-oxodG levels among breast cancer patients. Low 8-oxodG levels both in serum and in breast cancer cells strongly indicate a more aggressive disease, especially in ductal carcinomas. Negative 8-oxodG immunohistochemical staining is a powerful prognostic factor in breast carcinoma patients. The mechanism behind these results offers an attractive topic for future studies.

\section{ACKNOWLEDGEMENTS}

This study was supported financially by Päivikki and Sakari Sohlberg Foundation, Cancer Society of Northern Finland and Finnish Breast Cancer Group. The contributions of $\mathrm{Mr}$ Kari Mononen in collecting patient data, Ms Anne Bisi for her technical assistance and Mr Ari Sarpola for statistical support are greatly appreciated.

\section{REFERENCES}

Barnes DM, Camplejohn RS (1996) P53, apoptosis, and breast cancer. J Mammary Gland Biol Neoplasia 1: $163-175$

Cho SH, Choi MH, Lee WY, Chung BC (2009) Evaluation of urinary nucleosides in breast cancer patients before and after tumor removal. Clin Biochem 42: 540-543

Cooke MS, Evans MD, Dove R, Rozalski R, Gackowski D, Siomek A, Lunec J, Olinski R (2005) DNA repair is responsible for the presence of oxidatively damaged DNA lesions in urine. Mutat Res 574: 58-66

Cooke MS, Loft S, Olinski R (2008) Measurement and meaning of oxidatively modified DNA lesions in urine. CEBP 17: 3-14

Cooke MS, Olinski R, Evans MD (2006) Does measurement of oxidative damage to DNA have clinical significance? Clin Chim Acta 365: 30-49

Dincer Y, Himmetoglu S, Akcay T, Ersoy EY, Gunes KN, Tortum O (2007) Prognostic significances of oxidative DNA damage evaluated by

8-hydroxy-deoxyguanosine and antioxidant enzymes in patients undergoing resection of gastric and colon carcinoma. Neoplasma 54: 131-136 Evans MD, Cooke MS (2006) Oxidative damage to DNA in non-malignant disease: biomarker or biohazard? Genome Dyn 1: 53-66

Farinati F, Cardin R, Bortolami M, Nitti D, Basso D, de Bernard M, Cassaro M, Sergio A, Rugge M (2008) Oxidative DNA damage in gastric cancer: CagA status and OGG1 gene polymorphism. Int J Cancer 1: 51 - 55

Hirano T (2008) Repair system of 7, 8-dihydro-8-oxoguanine as a defense line against carcinogenesis. J Radiat Res 49: 329-340

Hussain SP, Raja K, Amstad PA, Sawyer M, Trudel LJ, Wogan GN, Hofseth LJ, Shields PG, Billiar TR, Trautwein C, Hohler T, Galle PR, Phillips DH, Markin R, Marrogi AJ, Harris CC (2000) Increased p53 mutation load in nontumorous human liver of wilson disease and hemochromatosis: oxyradical overload diseases. Proc Natl Acad Sci USA 97: 12770-12775 
Jaruga P, ñski R, Biczysko W, Szyfter W, Nagy E, Möller L, Szyfter K (2003) Oxidative DNA base modifications and polycyclic aromatic hydrocarbon DNA adducts in squamous cell carcinoma of the larynx. Free Radical Res 37: $231-240$

Kaczmarek P, strok;aszczyk J, ałkowski P, rakowska-Fijałek A, Niemirowicz J, Kasprzak A, Baj Z (2005) Assessment of 8-hydroxy-2'-deoxyguanosine concentrations in bladder cancer patients treated with intravesical BCG instillation. Pol Merkur Lekarski 19: 526-528

Karihtala P, Mäntyniemi A, Kang SW, Kinnula VL, Soini Y (2003) Peroxiredoxins in breast carcinoma. Clin Cancer Res 9: 3418-3424

Karihtala P, Soini Y (2007) Reactive oxygen species and antioxidant mechanisms in human tissues and their relation to malignancies. APMIS 115: $81-103$

Kuo HW, Chou SY, Hu TW, Wu FY, Chen DJ (2007) Urinary 8-hydroxy-2'deoxyguanosine (oxodG) and genetic polymorphisms in breast cancer patients. Mutat Res 631: 62-68

Lau A, Villeneuve NF, Sun Z, Wong PK, Zhang DD (2008) Dual roles of Nrf2 in cancer. Pharmacol Res 58: 262-270

Lee BM, Jang JJ, Kim HS (1998) Benzo[a]pyrene diolepoxide-I-DNA and oxidative DNA adducts associated with gastric adenocarcinoma. Cancer Lett 125: $61-68$

Loft S, Poulsen HE (1996) Cancer risk and oxidative DNA damage in man. J Mol Med 74: 297-312

Matsui A, Ikeda T, Enomoto K, Hosoda K, Nakashima H, Omae K, Watanabe M, Hibi T, Kitajima M (2000) Increased formation of oxidative DNA damage, 8-hydroxy-2-deoxyguanosine, in human breast cancer tissue and its relationship to GSTP1 and COMT genotypes. Cancer Lett 51: 87-95

Matsumoto K, Satoh Y, Sugo H, Takamori S, Kojima K, Fukasawa M, Beppu T, Futagawa S (2003) Immunohistochemical study of the relationship between 8-hydroxy-2'-deoxyguanosine levels in noncancerous region and postoperative recurrence of hepatocellular carcinoma in remnant liver. Hepatol Res 25: 435-441

Miyake H, Hara I, Kamidono S, Eto H (2004) OxidativeDNA damage in patients with prostate cancer and its response to treatment. J Urol 171: $1533-1536$

Nagashima M, Tsuda H, Takenoshita S, Nagamachi Y, Hirohashi S, Yokota J, Kasai H (1995) 8-Hydroxydeoxyguanosine levels in DNA of human breast cancer are not significantly different from those of non-cancerous breast tissues by the HPLC-ECD method. Cancer Lett 90: 157-162

Nishigori C, Arima Y, Matsumura Y, Matsui M, Miyachi Y (2005) Impaired removal of 8-hydroxydeoxyguanosine induced by UVB radiation in naevoid basal cell carcinoma syndrome cells. $\mathrm{Br}$ J Dermatol 153: 52 - 56

Okamoto K, Toyokuni S, Uchida K, Ogawa O, Takenewa J, Kakehi Y, Kinoshita H, Hattori-Nakakuki Y, Hiai H, Yoshida O (1994) Formation of 8-hydroxy-2'-deoxyguanosine and 4-hydroxy-2-nonenal-modified proteins in human renal-cell carcinoma. Int J Cancer 58: 825-829

Oliva MR, Ripoll F, Muñiz P, Iradi A, Trullenque R, Valls V, Drehmer E, Sáez GT (1997) Genetic alterations and oxidative metabolism in sporadic colorectal tumors from a Spanish community. Mol Carcinog 18: 232-243

Paz-Elizur T, Ben-Yosef R, Elinger D, Vexler A, Krupsky M, Berrebi A, Shani A, Schechtman E, Freedman L, Livneh Z (2006) Reduced repair of the oxidative 8-oxoguanine DNA damage and risk of head and neck cancer. Cancer Res 66: 11683-11689

Paz-Elizur T, Krupsky M, Blumenstein S, Elinger D, Schechtman E, Livneh Z (2003) DNA repair activity for oxidative damage and risk of lung cancer. J. Natl Cancer Inst 95: 1312-1319

Peoples MC, Karnes HT (2005) Recent developments in analytical methodology for 8-hydroxy-2'-deoxyguanosine and related compounds. J Chromatogr B Analyt Technol Biomed Life Sci 827: 5-15

Romano G, Sgambato A, Mancini R, Capelli G, Giovagnoli MR, Flamini G, Boninsegna A, Vecchione A, Cittadini A (2000) 8-Hydroxy-2'-deoxyguanosine in cervical cells: correlation with grade of dysplasia and human papillomavirus infection. Carcinogenesis 21: 1143-1147

Ross JS, Slodkowska EA, Symmans WF, Pusztai L, Ravdin PM, Hortobagyi GN (2009) The HER-2 receptor and breast cancer: ten years of targeted antiHER-2 therapy and personalized medicine. Oncologist 14: 320-368

Shen J, Deininger P, Hunt JD, Zhao H (2007) 8-Hydroxy-2'-deoxyguanosine (8-OH-dG) as a potential survival biomarker in patients with nonsmallcell lung cancer. Cancer 109: 574-580

Singh A, Boldin-Adamsky S, Thimmulappa RK, Rath SK, Ashush H, Coulter J, Blackford A, Goodman SN, Bunz F, Watson WH, Gabrielson E, Feinstein E, Biswal S (2008) RNAi-mediated silencing of nuclear factor erythroid-2-related factor 2 gene expression in non-small cell lung cancer inhibits tumor growth and increases efficacy of chemotherapy. Cancer Res 68: $7975-7984$

Slamon DJ, Clark GM, Wong SG, Levin WJ, Ullrich A, McGuire WL (1987) Human breast cancer: correlation of relapse and survival with amplification of the HER-2/neu oncogene. Science 235: 177-182

Sentürker S, Karahalil B, Inal M, Yilmaz H, Müslümanoglu H, Gedikoglu G, Dizdaroglu M (1997) Oxidative DNA base damage and antioxidant enzyme levels in childhood acute lymphoblastic leukemia. FEBS Lett 416: $286-290$

Tavassoli FA, Devilee P (2003) World Health Organization Classification of Tumours. Pathology and Genetics of Tumours of the Breast and Female Genital Organs. IARC Press: Lyon

Toyokuni S, Tanaka T, Hattori Y, Nishiyama Y, Yoshida A, Uchida K, Hiai H, Ochi H, Osawa T (1997) Quantitative immunohistochemical determination of 8 -hydroxy-2'-deoxyguanosine by a monoclonal antibody N45.1: its application to ferric nitrilotriacetate-induced renal carcinogenesis model. Lab Invest 76: 365-374

Turunen N, Karihtala P, Māntyniemi A, Sormunen R, Holmgren A, Kinnula VL (2004) Thioredoxin is associated with proliferation, p53 expression and negative estrogen and progesterone receptor status in breast carcinoma. APMIS 112: $123-132$

Valko M, Izakovic M, Mazur M, Rhodes CJ, Telser J (2004) Role of oxygen radicals in DNA damage and cancer incidence. Mol Cell Biochem 266: $37-56$

Vulimiri SV, Wu X, Baer-Dubowska W, Andrade Md, Detry M, Spitz MR, DiGiovanni J (2000) Analysis of aromatic DNA adducts and 7,8-dihydro8-oxo-2' deoxyguanosine in lymphocyte DNA from a case-control study of lung cancer involving minority populations. Mol Carcinog 27: $34-46$ 